\title{
THE ROLE OF MULTIMODALITY LABS IN MULTILITERACY PROJECTS ${ }^{1}$
}

Fábio Alexandre Silva Bezerra

Universidade Federal da Paraíba

Roseli Gonçalves do Nascimento

Universidade Federal de Santa Maria

\begin{abstract}
In contemporary society, there has been an increasing pervasiveness of images, sounds, shapes and bodily expressions in our everyday lives. A number of academic studies have addressed such meaning-making resources in varying theoretical and methodological perspectives, with the general goal of describing and understanding how these semiotic modes 1) are constituted, 2) construe representations of our experiences in the world, and 3) can be addressed in educational contexts in order to help learners be more apt to function in such new configurations of texts and media. Therefore, this paper presents an overview of research carried out in five multimodality labs across the world, with special attention to the relevance of their work as far as multiliteracies are concerned. Firstly, we review the set-up of each lab and highlight their contributions, research
\end{abstract}


strengths and recent projects. Finally, we discuss some of the similarities and distinctive aspects of these labs in order to offer a sense of the co-ordinated work across them and to promote greater awareness of their contributions.

Keywords: multimodality; research labs; multiliteracies; semiotic modes.

\section{Introduction}

The adage $A$ picture is worth a thousand words has never been so conspicuously appropriate as in our contemporary society, when the role of semiotic modes ${ }^{2}$ other than verbal language has been the focus of a number of studies (Thibault, 2000; Iedema, 2003; Kress \& van Leeuwen, 2006 [1996]; Heberle \& Meurer, 2007; O’Halloran, 2007; Böhlke, 2008; Bezerra, Nascimento \& Heberle, 2010). In this respect, it is important to highlight that, despite the greater attention that has been paid to the meaning-making potential of still images, there are also other semiotic resources and multimodal texts that need to be taken into consideration when designing multiliteracy pedagogy projects, such as internet sites, three-dimensional spaces, sculptures, architecture, body language and films (Baldry \& Thibault, 2005; Knox, 2007; Kress, 2003; Kress \& van Leeuwen, 2006 [1996]; O'Halloran, 2008; O’Toole, 1994; Stenglin, 2009; Unsworth, 2001).

In order to develop further investigation about the multiple modes and media that are used to produce, distribute and interpret meanings in our world for a number of different purposes, as well as aiming to advance current pedagogical practices, we need to reexamine current literacy projects in order to include the notion of multiliteracies (Unsworth, 2001). In that regard, we build on The New London Group's definition of multiliteracy as “a new approach 
to literacy pedagogy" (1996, p. 60) which aims at responding to the needs of a society facing important social and cultural changes, especially in regards to the way teachers and students interact with each other and with a new range of texts that increasingly become more multimodal. In this new pedagogy, "other modes of meaning are dynamic representational resources, constantly being remade by their users as they work to achieve their various cultural purposes" (ibid, p. 64).

Drawing on the proposal by The New London Group, in this paper, we discuss the relevance of research oriented towards multimodality to foster projects of multiliteracies. We do so by providing an overview of the aims and research foci of five labs across the globe that develop research on multimodality, either as a core mission or as one key orientation, focusing on their recent and potential contributions for the field.

\section{Multiliteracies}

The move to pedagogies of multiliteracies gains special relevance considering the impact of educational practices in the context of the pervasiveness of multimodal texts. Besides the multimodal texts that permeate students' lives in a range of communicative situations outside the classroom, they also need to deal with textbooks where image-text relations have been re-designed. This new educational configuration is described by Luke (2006, p. 270) when she states that

[t]hroughout the last decade, notions of a singular printbased literacy have been reconceptualized into hyphenated or multiple literacies that acknowledge the diversity of information sources and media that people access, negotiate, and redeploy in everyday contexts. 
Hence, students should have the opportunity to experience a literacy pedagogy that allows for them to work with a range of texts in varied modes and media, thus being an alternative to the traditional project that has long been "restricted to monolingual, monocultural, and rule-governed forms of language" (Cope \& Kalazantis, 2000 as cited in Somerville, 2008, p. 9).

We would also like to emphasize that multiliteracy projects should take into account students' sociocultural background in order to use texts that are relevant for them as well as to expand their repertoire. This concern is supported by Kress and van Leeuwen's (2006 [1996]) claim that "meanings belong to culture, rather than to specific semiotic modes" (p. 2) and Gee's (2000) argument that "meaning is always situated in specific sociocultural practices and experiences" (p. 195).

Thus, to develop multiliteracy projects, we also need to account for the literate practices in which students are engaging in the classroom as well as the view of language that will inform our educational practice "in order that informed, resistant and subversive reading practices can be learned and taught" (Knox, 2007, p. 48). Being able to read a multimodal text is very important in a society where people are constantly bombarded with images and verbal language put together in a myriad of layouts across modes, media and genres, especially with the solidification of the internet.

Even though it is not our intent to present the metalanguage in Kress and van Leeuwen's (2006 [1996]) Grammar of Visual Design (GVD), we would like to argue for the importance of overt instruction (The New London Group, 1996), when students will be taught the metalanguage to analyze both textual and visual texts in order to "facilitate systematic attention by teachers to the multimodal nature of texts in developing critical literacy practices" (Unsworth, 2001, p. 
72). In other words, teachers should provide students with the tools to understand that "certain images and ideas about the world are favoured or presented as 'normal', while other possibilities as excluded, either implicitly or explicitly" (Callow, 1999, p. 2) as well as that "visual language is not (...) transparent and universally understood; it is culturally specific" (Kress \& van Leeuwen, 2006, p. 4).

As Unsworth (2001) claims, even though "[w] ritten texts have always been multimodal" (p. 9), as regards font, size, color, spacing, layout and texture, "we have been taught to overlook this kind of multimodality" (ibid, p. 9), or, as stated by Machin (2007), instead of "communication becoming more visual, it is rather the case that the different modes, traditionally separated, have merged and combined" (p. 20). In today's society, however, we are continuously required to acknowledge the "growing impact of images in an increasing range of texts and the shift from page to screen-based literacies" (ibid, p. 1).

In that respect, Kellner (2006) explains that " $t$ t]he dramatic multiplication of computer, information, communication, and multimedia technologies has been changing everything from the ways people work, to the ways they communicate with each other and spend their leisure time" (p. 241). ). Consequently, education has a central role in the process of helping students to become more apt to act in such a demanding and constantly changing environment, especially for the fact that, for instance, "[t]he semiotic mode of images has a central educational function in supporting children's control over resources in the visual sphere" (Hopperstad, 2008, p. 77).

This attitude does require that teachers change their traditional projects to include the texts, modes and media that have more often than ever been in their students' lives and that are the result of technological advancements and sociocultural changes (Kellner, 2006). However, this is not an easy change; it may cause, as described 
by McDougall (2010), a crisis in teachers' identity created by the dilemmas they face when confronting the old and the new demands of the educational scenario. McDougall (ibid) argues that this is a crisis that "will remain unless the boundaries that separate conventional literacies from new literacies can be challenged" (p. 679).

Additionally, technological progress has strongly impacted the way our students communicate, and, in this context, educators need to re-shift their practices to include alternatives to deal with these new ways of experiencing the world. Outside the classroom, students send and receive text messages and e-mails, play videogames, chat on the internet, watch $3 \mathrm{D}$ movies, write on their personal web pages and $b l o g s$, and engage in a number of other practices that are mediated by new and highly sophisticated technologies.

In that sense, the work in multimodality labs has much to offer, since it focuses precisely on discussing and advancing theories and methodologies in the area as well as on keeping track of the extent to which such theories have been useful for actual classroom practice in multiliteracy projects. Besides contributing to cyclical praxis, these labs also aim at collecting data from classroom settings in order to inform further reflections, which may eventually lead to theoretical reformulations and implementation of new educational practices.

For the present study, the Multimodal Analysis Lab (National University of Singapore/Singapore), the Center for Multimodal Research (University of London/England), and the Multimodal Research Center (Auckland University of Technology/New Zealand) were selected for their international visibility. At the time this paper was produced, these were the only formally organized centers of research in multimodality we could identify ${ }^{3}$. Additionally, each lab represents a particular theoretical orientation to multimodality (see Jewitt, 2009) and is led by widely acknowledged scholars in the field. 
We also report on the Lab for Research and Teaching of Reading and Writing 4 (Federal University of Santa Maria/Brazil) and the Semiotic and Multimodal Research Lab ${ }^{5}$ (Federal University of Santa Catarina/ Brazil), which are meant to represent the more recent enthusiasm around multimodality and multiliteracies in the Brazilian context, where the present authors have contributed. Our aim is to provide a sense of the co-ordinated research work across different labs and to promote greater awareness of these labs and their contributions.

In the next section, we review each of the labs. The order of presentation follows the criterion of chronology, starting from the oldest labs to the most recently founded ones.

\section{Lab for Research and Teaching of Reading and Writing ${ }^{6}$}

\subsection{Background}

The Lab for Research and Teaching of Reading and Writing (LabLeR) was founded by Dr Desiree Motta-Roth at the Federal University of Santa Maria, Brazil, with the aim of fostering the qualification of pre-service language teachers as well as contributing to the development of multiliterate practices in school and university levels.

LabLeR was created in 1998, at the Federal University of Santa Maria, as optional complementary education under the belief that language majors need to experience the indissolubility between research, teaching and university intervention. This center, which is open to all pre-service language teachers majoring in Letters and/or Languages, encourages awareness regarding the process of language teaching/learning by means of theoretical reflection and pedagogical practice, design and production of 
142 Fábio Alexandre S. Bezerra and Roseli G. do Nascimento, The role of...

teaching materials, and by evaluation and intervention at any moment of the process (LabLeR homepage).

LabLer is defined as a site for continuous linguistic and pedagogic experimentation and knowledge pursuit. As part of a larger institutional program to empower students from low economic backgrounds, the lab has promoted multiliteracy education - foreign languages, digital literacy, multimodal literacy, and Languages for Academic Purposes - to students from several fields. In this symbiotic project, pre-service language teachers experience controlled, though real, classroom situations where they can build up teaching skills, while students from other departments can enhance their participation in the multiliterate practices within their respective field ${ }^{7}$.

As a whole, LabLeR functions as a complementary, though highly sophisticated, four-phased language teacher education program comprising: 1) Observation; 2) Practice; 3) Intellectual Authorship; and 4) Theoretical-Pedagogical Reflection. The key aspects are intellectual mentorship and informed participation in the community of practice. From early stages, students are encouraged to participate in multiliterate practices of knowledge production (e. g. designing and presenting academic communication, designing, editing and publishing instructional materials, co-producing and submitting research proposals, co-authoring papers) and reflection over their own pedagogical intervention in light of critical genre theories.

This dynamics of team work in a constant relation of theory and practice has created conditions for the foundation of the research group 'Language as Social Practice', which has been working interinstitutionally with other groups such as 'NUPDiscurso (Text, 
Discourse and Social Practices) from the Federal University of Santa Catarina in Florianopolis, Brazil.

\subsection{Contributions, Research Strengths and Recent Projects}

Investigations in the lab draw on cross-bred theoretical orientations by the adoption of Critical Discourse Analysis, SocialInteractionist approaches to learning, Critical Genre Analysis, Social Semiotics, and Systemic-Functional Linguistics.

Narrowed down to the scope of this paper, we wish to highlight LabLer's contributions on three main topics: 1) multimodal analysis and literacy; 2) digital media and teaching; and 3) digital genres and hypermodality. In terms of rationale, the group departs from the relevant role played by electronic genres and technology as motivating tools for enhancing students participation in knowledge construction (Motta-Roth, 2005; Motta-Roth et al, 2007), as well as on their long tradition of investigating academic genres added by further observations that such genres are semiotic hybrids (Lemke, 1998) that have been greatly impacted by new technologies of communication to the point of becoming 're-semiotized', (Iedema, 2003).

On multimodal analysis and literacy, examples include: analysis of how ideational/representational and interpersonal/interactive meanings are projected in video texts (e. g. Motta-Roth $\&$ Nascimento, 2010); text-image relationships in media print genres (e. g. Catto \& Hendges, 2009; Hendges et al, forthcoming); and multimodality in academic genres (Nascimento, 2002; Nascimento \& Motta-Roth, 2004; Hendges, 2006a); as well as a pedagogical project aimed at developing multimodal literacy in EFL contexts ('Videos as texts's). LabLeR has also organized and hosted two editions (2011 and 2012) of an international conference on Multiliteracies ${ }^{9}$, with distinguished 
144 Fábio Alexandre S. Bezerra and Roseli G. do Nascimento, The role of...

plenary speakers in the field such as Bill Cope, Brian Street and Walkyria Monte Mór.

On digital media and teaching, we can highlight studies that evaluate pedagogical tools in print (Ticks, 2003) and electronic formats (Weissman, 2005; Oliveira, 2009) and the design, application and assessment of pedagogical materials in print ('Academic Writing' ${ }^{10}$ ) and digital formats ('Surfing on the web" ${ }^{11}$, 'WebEnglish ${ }^{12}$, 'Español Online'13, and 'Reading Online'14).

Besides its strong pedagogical orientation, one main contribution of LabLeR to the field is describing the role played by different semiotic resources and communication media in processes of generic transformation and recontextualization. For example, a line of inquiry focuses on the extent to which and how moves from traditional to electronic media go beyond form and materials and can be interpreted as functional developments (Hendges, 2006b, MottaRoth et al. 2000; Hendges, 2008). Another example is the observation that images fulfil specialized semiotic jobs that are closely associated to generic features (Motta-Roth \& Hendges, 2010; Nascimento, 2012) and to the process of recontextualization of discourse across genres and domains (e.g. from the research article in the academic context into the pop science article in the media context) (Hendges et al, forthcoming).

\section{Multimodal Analysis Lab}

\subsection{Background}

The Multimodal Analysis Lab (MAL) was established as an interdisciplinary research institute at the National University of Singapore in 2007. As part of the Interactive Digital Media Institute 
at the National University of Singapore, the lab originated from the Semiotics Research Group founded by Professor Kay O'Halloran ${ }^{15}$ in 1999.

In early investigations on a range of multimodal texts, the group was faced with the limitations of employing page-based methodologies and existing commercial software applications. This challenge seemed to drive the team into endeavors "to develop new approaches to multimodal analysis using computer-based techniques of multimedia analysis, social semiotic theory and other interdisciplinary perspectives" (MAL homepage).

Visual images (e.g. photographs, drawings and diagrams) and video texts remain elusive with regards to management, coding and searching for information. The problem intensifies as videosharing websites become the standard forum for exchanging information. Dynamic digital texts clearly require theoretical concepts and analytical approaches which extend beyond those developed for text-based data (ibid).

The main contributions of the lab seem to derive from the integration of interactive digital technology into multimodal semiotic analysis. According to O'Halloran (2007, p. 19), digital technology offers "a platform for real time interactive and realistic visualization" of how meanings arising from semiotic choices combine over time. Here they touch on what seems to be the chief obstacle for researchers used to analyzing written language-spatially organized and static, who set out to invest in new territories, where meaning is organized and ruled by the logic of time, such as in audios or videos, or, even more complexly, in communicative events simultaneously governed by the logics of time and space. 
146 Fábio Alexandre S. Bezerra and Roseli G. do Nascimento, The role of...

\subsection{Contributions, Research Strengths and Recent Projects}

As indicated above, the MAL has contributed to the area of multimodality by incorporating and exploring the potentials of digital technology. Their objectives are 1) to develop software and methods (e. g. O'Halloran et al, 2010) for modeling, analyzing, storing and retrieving meaning arising in print and electronic texts as well as interactive digital sites (e. g. O'Halloran et al. 2011), including learning materials and classroom activities $\left.{ }^{16} ; 2\right)$ to investigate the dynamics of complex semiotic practices (e. g. O'Halloran; 2008; Liu \& O'Halloran, 2009; Lim, 2011; Lim et al., 2012); and 3) to critically examine the affordances and constraints of technology in its different forms (e. g. O'Halloran \& Tan, 2009).

New perspectives to achieve these aims are probably the result of a highly specialized and multidisciplinary research team configuration. Systemic-functional linguistics, social semiotics and multimodal discourse analysis provide the general directions for investigation. Nonetheless, a substantial part of the team has background in areas such as mathematics, computer science, electrical engineering, technological design, electronic systems, which extends the lab's expertise for developing computer-based multimedia techniques and interactive digital platforms. These tools attempt to replicate the very meaning potential of dynamic texts such as in websites and videos. "For example, changes in the facial expressions may be mapped and coded using 2D / 3D graphics for real-time techniques for face detection, face recognition, face tracking and 3-D face modeling" (Idem).

In addition to this multidisciplinary configuration at the technical level, so to speak, the MAL-Singapore is associated to an international network of intellectual collaborators. Professor Theo van Leeuwen, from the University of Technology, Sydney, provides 
directions for the modeling and multimodal analysis of texts using his widely acknowledged expertise on language, visual imagery, music and sound tracks. Another external collaborator, Professor Kevin Judd, from the University of Western Australia, a mathematician with experience in dynamical systems theory and computer aided teaching, developed Systemics 1.0 - software for linguistic analysis. Other central figures in Systemic-Functional Linguistics and Multimodal Discourse Analysis, such as Michael O'Toole, Eija Ventola, Jim Martin, Anthony Baldry, and Paul Thibault, have also played a part as visiting Professors.

To illustrate, three recent projects developed at the MAL in association with external collaborators can be mentioned: 1) "Assessing 21st Century Competencies through Interactive Digital Media Challenge" (Kay O'Halloran, Roger Zimmerman, Philip McConnell, and Mark D Gross) (2) 'Towards a Social Theory of Semiotic Technology ${ }^{17}$ (Theo van Leeuwen, Emilia Djonov, and Kay O'Halloran), an investigation on the use of PowerPoint in higher education and corporate settings focusing on how the software design supports or hinders the achievement of a range of communicative purposes; and 3) 'Mapping Asian Cultures' (Kay O'Halloran; Robbie Goh; Giorgos Cheliotis), on digital humanities and cultural analytics, whose aim is to identify patterns in the cultural development of Asia and to detect new cultural currents in the media.

\section{Centre for Multimodal Research}

\subsection{Background}

The Center for Multimodal Research (CMR) of the London School of Education at the University of London is an important 
locus of investigation in the field of multimodality connected to issues of teaching, under co-direction of Professor Gunther Kress and Dr Jeff Bezemer. The center "undertakes research and offers training courses and consultancy services" (CMR homepage ${ }^{18}$ ) in the areas of: 1) representation and communication; 2) learning and assessment; 3) technology and new media; and 4) research methods.

The lab draws on the well established tradition of Social Semiotics (Hodge \& Kress, 1988) and general principles of Systemic Functional Linguistics (Halliday, 1978). It is widely known that many influential publications by its researchers precede the official launching of the lab.

\subsection{Contributions, Research Strengths and Recent Projects}

Members of the CMR have been particularly influential in the development of the multimodal research community locally at the Institute of Education, nationally and internationally by developing research around the following topics: students production - spoken, written, and drawing - from the perspective of multimodal literacy (e. g. Bezemer \& Kress, 2008; Flewitt, 2012; Mavers, 2008, 2011); design and use of multimodal learning resources (e. g. Agarwall-Hollands \& Andrews, 2001; Lewin et al, 2003); social semiotics and multimodal theory and methods (e.g. Bezemer \& Jewitt, 2009; Bezemer \& Mavers, 2011; Kress \& van Leeuwen, [1996] 2006; Kress \& van Leeuwen, 2001); multimodal discourse across the curriculum (e. g. Kress et al., 2005); technology mediated learning and teaching (e. g. Andrews \& Smith, 2011); and multimodal classroom research (e.g. Jewitt, 2008).

Some recent projects by the group ${ }^{19}$ include: 'Digital Technologies in the Operating Theatre' (Jeff Bezemer, Roger Kneebone and Gunther Kress), a social semiotic account of how digital technologies can improve clinical care and training; 'Researching embodiment 
with digital technologies' (Sara Price and Carey Jewitt), a study of how digital technologies can enhance bodily-based experiences; 'Transient Teams in the Operating Theatre: A Case Study of Changing Social and Economic Contexts for Clinical Communication' (Jeff Bezemer, Gunther Kress, Roger Kneebone and Kathryn Nicholson), a research aimed at investigating professional communication in 'transient teams'; and projects by and large described here as aiming to increasingly understand and describe the nature and processes involved in teaching and learning in the multimedia age.

\section{Multimodal Research Centre}

\subsection{Background}

Organically, the Multimodal Research Centre (MRC) developed out of the precedent Multimodal Research Group, after Dr. Sigrid Norris joined the School of Communication Studies at Auckland University of Technology, Auckland, New Zealand. By early 2009, the group had developed into "a strong network of researchers with a core interest in multimodal discourse, multimodality, and multimodal interaction analysis" (MRC homepage ${ }^{20}$ ). At this point, the Faculty of Design and Creative Technologies identified the opportunity to create a more formal structure. Thus, on October $23^{\text {rd }}, 2009$, the MRC was officially launched under the direction of Dr. Sigrid Norris.

As for theoretical affiliations, the work in the MRC is "largely inspired by Ron Scollon and his work in Mediated Discourse Analysis" (MRC homepage), one of its missions reported as being to extend Scollon's work and, additionally, to expand multimodal interaction analysis, and to bridge work conducted at the center with any other forms of multimodal discourse analysis. In view of such general 
orientation, researchers state their position as adopting "a multimethodological and multitheorethical approach to contribute to and to advance academic inquiry" (MRC homepage) in multimodality.

\subsection{Projects, Research Interests and Strengths}

The MRC's vision is to map new regions in any type of communication, discourse, and interaction by using and developing multimodal frameworks with the aim of further developing multimodal methodology and theory in connection with practical advances in social life. Researchers from diverse areas of social science research are joined under the beliefs that all communication is multimodal and that all areas of social life are based on and touched by communication in some form.

Our goal in the MRC is to contribute to academic investigation by furthering methodological and theoretical frameworks for multimodality, multimodal discourse, and multimodal interaction; to broaden the theory-practice nexus; and to positively impact the social communities we serve. (MRC homepage)

On such belief, the newly established center defines its proposal for developing research concerning: 1) multimodal discourse analysis (e. g. Norris, 2009; White, 2010);2) multimodal interaction analysis (Norris, 2011);3) multimodal identity construction, consisting of various case studies using video ethnography and sociolinguistic interviews to examine identity construction in different settings (Norris, 2010, 2011), 4) multimodal media, involving investigations of diverse communication media as multimodal constructs; 5) digital technologies discourse, studies on the design, mandate, and 
application of digital technologies such as software; 6) mediated education, comprising studies on educational tools and methods from a multimodal perspective, such as analysis of mediating technologies, questions of multimodal learning and teaching, as well as issues of education transfer; 7) multimodal anthropology, focusing on studies of human discourse by use of multimodal methodologies (Frommherz, 2010); 8) multimodal aesthetics, exploring constructed realities as artifacts and the relationship between artifact and spectator; and 9) audience reception.

In order to provide the reader with a glimpse of how these themes are explored in the lab, we now briefly describe a few projects related to the aforementioned themes. To illustrate, in multimodal discourse analysis, 'Attention in the age of information overload' (Paul White) focuses on how people interact with marketing communications mediated by conventional media and by a convergence of old and new technologies, while 'Horseback Riding Lessons' (Sigrid Norris) investigates the inter-connected nature of senses and the modes in comparing horseback riding and the teaching of this ability.

In multimodal interaction analysis, 'Workplace Practices' (Sigrid Norris), workplaces are studied using video ethnography coupled with sociolinguistic interviews and document analyses to add to our understanding of workplace communication, whereas in 'Interactive Gaming' (Sigrid Norris, Paul Brafield, Gudrun Frommherz, and Fadhil Abdullah), they investigate the interactivity of gaming practices in teenagers and young adults.

Within mediated education, a project entitled 'Multimedia Learning Objects' (Gudrun Frommherz) is directed at overcoming key constraints for multimedia use in teaching and learning situations, by proposing flexible approaches designed in reusable modules with adaptable delivery. 
152 Fábio Alexandre S. Bezerra and Roseli G. do Nascimento, The role of...

Under digital technologies discourse, researchers of 'Motion Capture' (Gregory Bennett) concentrate on digital apprehension of dramatic performance and its application to computer generated 3D characters with potential applications for rehabilitation and occupation studies. In audience reception, 'Consumerism \& Sustainability' (Dave Brown) looks at how consumers respond to purchasing products and are influenced by persuasive or factual information about those products.

\section{Semiotic and Multimodal Research Lab ${ }^{21}$}

\subsection{Background}

The Semiotic and Multimodal Research Lab (LabSeM) has been recently founded by Dr Viviane Maria Heberle at the Federal University of Santa Catarina (UFSC) in Brazil, aiming to investigate new forms of communication and the use of different visual and multimedia resources to produce and interpret meanings in contemporary society.

LabSeM is directly linked to continued investigation into the area of Applied Linguistics across a number of different studies carried out by members of the research group Text, Discourse and Social Practices (NUPDiscurso) at UFSC, which was founded in 1997 by Professor José Luiz Meurer and Dr Viviane Maria Heberle. Therefore, it is important to describe some of the history of this latter group in order to understand this move towards a specific multiliteracy research project to be undertaken at LabSeM.

NUPDiscurso develops research aimed at describing, interpreting and/or explaining lexicogrammatical, discursive 
and social aspects of the use of language in institutional and/ or professional environments. The group applies and seeks to produce theoretical and methodological knowledge in the areas of genre, gender, critical discourse analysis, systemicfunctional linguistics and social theories about the interrelation between language and society. Researches carried out (...) aim to provide support for teachers and students about varied textual manifestations (...) in order to contribute for the development of a better understanding of the role and the power of language (...) as well as to have practical implications in regards to the analysis and production of texts in school settings. ${ }^{22}$ (Rüther \& Montenegro, 2009, p. 285)

Members of NUPDiscurso include both doctoral and postdoctoral scholars from UFSC and other universities in Brazil as well as undergraduate, MA and doctoral students at UFSC. They develop investigations on a number of different topics across the lines of teacher education, multimedia, multimodal and academic texts, political and institutional discourses. A number of research results have been published both nationally and internationally (e. g. Almeida, 2009; Bezerra, 2011; Ferreira, 2007; Heberle, Ostermann \& Figueiredo, 2006; Heberle \& Meurer, 2007; Meurer, 2004; Santiago \& Meurer, 2008; Souza, 2006) making NUPDiscurso an active group in the area of Applied Linguistics.

Based on her experience at NUPDiscurso with developing research in the area of multiliteracies in public schools, Dr Heberle decided to create a research group that would work specifically with the pressing needs of today's society in being able to deal with multimodal texts in a wide range of multimedia, especially in school contexts so as to develop and consolidate a multiliteracy project. LabSeM has been active for the past four years, during which research results have been published (Bezerra, 2012; Bezerra, Nascimento \& 
154 Fábio Alexandre S. Bezerra and Roseli G. do Nascimento, The role of...

Heberle, 2010; Ferreira \& Heberle, 2010; Heberle, 2010; Heberle \& Abreu, 2012; Nascimento, Bezerra \& Heberle, 2011), members have presented research results in a number of national and international conferences and they regularly discuss varied topics related to the main scope of the research lab as well as share the progress of their own work. Such collective work has helped to bring continued innovation into the area of literacy pedagogy in Brazil, based on the interconnection between Systemic-Functional Linguistics, Critical Discourse Analysis as well as Multimodality and Multiliteracy.

\subsection{Contributions, Research Strengths and Recent Projects}

The studies by members of NUPDiscurso have shown relevant results, especially concerning gender (Bezerra, 2008, 2012; Böhlke, 2008; Heberle, 1997; Ostermann, 1995; Prawucki, 1998), genre (Souza, 2006; Nascimento, 2012) and teacher education (Heberle \& Meurer, 2007).

Now, drawing on the experience at NUPDiscurso, members of LabSeM have started a project aimed at applying existing theory and methodology, as well as at advancing new ones, for the development of a new pedagogy in the Brazilian school context which focuses on making students able to interact competently with the multimodal and multimedia texts that permeate our everyday lives.

\section{Wrap-up}

Apart from the fact that all the labs and centers described in this paper develop research in multimodality/multiliteracies to different extents, we would like to establish a few connections and then highlight idiosyncrasies of each lab. 
As we have attempted to demonstrate, all five labs described above seem to be unified by the claim that people construct meaning and communicate through a range of resources that may include, but go beyond verbal language in conventional media (Nascimento, 2012, p. 29). At different degrees, the labs have developed research and technologies that can inform the development of projects of multiliteracies at different educational levels that contribute to "the advancement of skills in digital technologies [...] deemed necessary to ensure that the workers of tomorrow are suitably prepared" (McDougall, 2010, p. 680).

In terms of set-up, the labs either originate from a productive research group based in the institution or, conversely, it is the systematic work in the laboratory team that provides the necessary conditions for the development of a research group - such as in the case of LabLeR.

A second shared aspect is the multidisciplinary configuration of teams. All labs seem to foster dialogue with approaches other than linguistics, involving semiotics and social sciences, some being directly informed by researchers from technical fields, which allows them to address the complexity of developing methods for multimodal annotation and analysis. Synergetic work with areas such as computer science and mathematics, for instance, can offer solutions that would, in principle, be beyond the capacity of linguists and social semioticians. Establishing these partnerships seems productive to increase the labs' capacity to develop tools to model intrinsically dynamic texts, modes and practices, for which existing language-based tools are not directly applicable.

A third predominant aspect among these labs is an inclination to operate within international networks. Some very productive and widely acknowledged scholars in multimodality are members 
Fábio Alexandre S. Bezerra and Roseli G. do Nascimento, The role of...

in laboratories other than those of their home institution. Three of the labs described here-CMR, MAL and CMR-have international committees $^{23}$, which reveals research collaboration and points out to political alliances, and attempt to gain territory by amplifying scholars' participation, given the fresh status and flexible boundaries of multimodal research analysis.

Besides these similarities, unique features can be pinpointed for each lab in relation to the others. According to official records, LabLeR has a longer record-over ten years-while the other labs seem to originate as direct outcomes of the recently aroused interest in multimodality. Perhaps we could say these labs are as fresh as their research field. Despite ground-breaking publications exploring the semiotic potential of resources other than verbal language in the late 1990s (O’Toole, 1994, Kress \& van Leeuwen, [1996] 2006, van Leeuwen, 1999), multimodal research did not immediately gain the status of a field. It was not until recently that the then-proposed frameworks were significantly adopted, explored and extended in multimodal approaches to communication.

This can also explain the scope of research across labs. In LabLeR, multimodal discourse analysis responds for a complementary fraction of an all-inclusive line of inquiry. Only in recent times has multimodality evolved into a niche of investigation per se in this lab. Differently, in MAL, CMR, MRC and LabSeM, multimodality is the very heart of the matter, since a whole concurrence of venues, facilities, research funding and scholarly interest was deliberately employed to develop multimodality as a field.

Even though they all represent the broad field of multimodality, each lab has created its own peculiar research space, partly as consequence of their leaders' academic heritage. For instance, the focus on the interactive and material aspects in communication 
by the MRC can be connected to its leader's affiliations with Geosemiotics, also referred to as discourses in place, while at LabLeR, a focus on multimodality and hypermodality in academic genres can be regarded as an influence ESP tradition of Genre Analysis. Moreover, each lab has formed its team by establishing new bonds with varied fields of study, either by counting on existing potential in their institutions or by attracting external human resources.

In that regard, the MAL has established partnership with technical fields such as computer science, mathematics and engineering, which brings digital technologies into the picture. This way, they have been able to conceive and extend methodologies to improve our understanding of how meaning is constructed in 'dynamic' multimodal texts.

Likewise, MRC is made up of a network of interdisciplinary researchers, who focus on multimodal theories and methodologies for communication in its broadest sense, looking at multimodal practices from the perspective of interaction and reception, which are relatively unexplored issues in the other labs reviewed here. Roughly speaking, we distinguish an anthropologically inspired approach to multimodal and mediated communication and the impact of multimodal products on participants.

Not only can we benefit by using such highly advanced tools to implement multimodal analysis of digital texts and mediated communication, but we can also take their example and consider strengthening existing teamwork with aligned research groups, as well as establishing new exchanges with complementary fields, which is something that LabSeM aims to do by developing collaborative work with the Department of Design also at Federal University of Santa Catarina, Brazil. 
From CMR, two aspects can be highlighted here. First, research in the lab often involves teaching/learning contexts or is intended for pedagogical applications, particularly concerning primary education. Second, we can learn from their expertise in adopting video-based methods for data collection and analysis. Both aspects are inspiring for LabSeM considering its aforementioned drive to examine multiliterate practices in schools both locally and nationally and its commitment with promoting positive intervention, particularly in public schools.

Besides its general orientation for critical pedagogies of multiliteracy, the main contributions from LabLeR and LabSeM come from their productive dynamics in professional apprenticeship and a common interest in TESOL, since they are located outside English-speaking contexts and have been strongly influenced by critical theories. Additionally, members of these labs share theoretical affiliations and have developed joint research (e.g. Meurer, Bonini \& Motta-Roth, 2005; Motta-Roth \& Heberle, 2005; Bezerra et al. 2010; Nascimento et al, 2011), a partnership which can be further explored with the development of LabSeM.

As we have illustrated, the work developed in these labs has contributed to the development and advance of theoretical understanding of multimodal phenomena. Some of them have more directly drawn on classroom data to improve the theory in an iterative manner. As a whole, a challenge remains as to how theoretical advances by these labs and other research centres can be re-contextualized into overt instruction, as we initially defended. On a positive note, we can highlight initiatives by two of the labs that have addressed such challenge. One of them is the TESOL education program at LabLeR, which involves a continuous process of production, application and re-evaluation of teaching materials ${ }^{24}$. 
This provides a convenient locus for the transposition and incorporation of metalanguage from multimodal genre analysis and multiliteracies in a controlled teaching environment. Another key example is the development of user-friendly software packages and resource books by the MAL, some of which aim directly at teachers and students (e.g. Tan et al. 2012).

At last, we should highlight the important role played by the labs' homepages within the international research community. The homepages concentrate information on each lab covering aspects such as history, research objectives, projects, identification of the team and announcement of events in the area. More than providing information, homepages can offer services such as recruiting new members - i.e. calls for positions, graduate scholarships - and allowing download of publications and products ${ }^{25}$.

In this paper, we have focused on the description of five multimodality labs by addressing the nature of their contributions to the field of multimodality/multiliteracies. We have also identified particular features and accomplishments in the first four labs LabLeR, MAL, CMR, and MRC - that can profitably be implemented into freshly established labs such as LabSeM at the Federal University of Santa Catarina, Florianopolis, Brazil. As a whole, different research inquiries entail different theories and approaches to multimodality (Jewitt, 2009; Nascimento, 2012). For example, Martin (2010) observes that activity theorists - such as the researchers in MRC see meaning as a kind of behavior involving verbal artifacts, while systemic-functional researchers equate gestures, for example, to language and then see action as a kind of meaning. Following this principle, we can say that the labs reviewed here can look at their objects of study in different ways. For some, they are viewed as multimodal texts, revealing linguistically oriented traditions, while 
others consider them multimodal practices, owing to preferred sociological approaches, and even others, from social semiotic perspectives, may look at similar objects as multimodal artifacts.

To conclude, we would like to acknowledge limitations of this paper. First, the review is predominantly descriptive so as to provide a quick and concise view of the co-ordinated research on multimodality and multiliteracies across institutionalized groups and to promote greater awareness of these labs, in particular those less visible in the anglo-dominant research world. Second, information was collected predominantly from the labs' homepages. A more in-depth review of the labs' effectiveness and accomplishments is required for future studies. This could be achieved, for instance, through email interviews and quotes from the directors of the labs and explicit references to their publications.

\section{Acknowledgments}

We would like to thank three anonymous reviewers for this journal for their detailed comments and relevant suggestions on earlier versions of this paper. Any mistakes that remain are our own.

\section{Notes}

1. Paper based on the project funded by the Brazilian Research Council CNPq (n. 481754/2009-1) and coordinated by Dr. Viviane Heberle.

2. We understand mode as "a socially and culturally shaped resource for making meaning" (Bezemer \& Kress, 2008, p. 250).

3. The information on the laboratories from Singapore and London was collected solely from their homepages and main publications.

4. Laboratório de Pesquisa e Ensino de Leitura e Redação (LabLeR).

5. Laboratório de Pesquisas Semióticas e Multimodais (LabSeM). 
6. Laboratório de Pesquisa e Ensino de Leitura e Redação (LabLeR).

7. The Languages Lab later evolved into further projects, which maintain the same theoretical and pedagogical principles, though are differently funded.

8. Nascimento, R. G. \& Hendges, G. R. (2003-2004). O vídeo como texto: explorando a multimodalidade na aula de inglês. LabLeR/FIPE/UFSM, Santa Maria.

9. Jornada de Multiletramentos.

10. Motta-Roth, D. \& Hendges, G. R. (Org.) (2010). Produção Textual na Universidade. São Paulo: Parábola Editorial.

11. Hendges, G. R. ; Motta-Roth, D. M. ; Cabral, R. E. ; Reis, Susana C. \& Roth, J. L . (1998) Surfando na Web. LabLeR, Santa Maria: UFSM.

12. Motta-Roth, D.; Cabral, R. E. \& Reis, D. C. (2001). WebEnglish. LabLeR, Santa Maria: UFSM.

13. Hendges, G. R. \& Fialho, V. R. (2000). A implementação do Espanhol Online: alguns aspectos de sua elaboração. In: XX Semana de Letras e VI Seminário Internacional de Língua e Literatura, Santa Maria.

14. Bortoluzzi, V. I. (2001). Reading online: leitura em inglês mediada por computador com foco em textos, discursos e gêneros. Dissertação (Mestrado em Letras), Universidade Federal de Santa Maria, Santa Maria.

15. Right before the printing of this journal issue, we learned that Professor Kay L. O'Halloran, director of the MAL, has moved to the School of Education in the Humanities Faculty at Curtin University, Australia. However, since our focus here is on the contributions of the lab to the field, we find it relevant to maintain the review as originally planned.

16. The MAL has released a software package for annotation and analysis of digital images and another for videos. The software tools as well as companion books and guides are intended to facilitate the teaching and learning of multimodal literacies. Other two packages are to be released in 2013: one for the analysis of texts and another for websites.

17. Projects will be identified by short names in this paper for matters of space, which often means the first segment of the project name before colons. 
18. http://www.ioe.ac.uk/research/163.html

19. As acknowledged previously, information for this paper was drawn from the labs' homepages and researchers' CVs made available online.

20. http://www.multimodalresearch.org/

21. Laboratório de Pesquisas Semióticas e Multimodais (LabSeM).

22. O NUPDiscurso realiza pesquisa com o intuito de descrever, interpretar e/ou explicar aspectos lexicogramaticais, discursivos e sociais do uso da linguagem em ambientes institucionais e/ou profissionais. Aplica e busca produzir conhecimento teórico e metodológico nas áreas de estudos de gênero (genre theory), gênero social (gender studies), análise crítica do discurso, lingüística sistêmica funcional e teorias sociais sobre a inter-relação entre a linguagem e a constituição da sociedade. As pesquisas realizadas (...) visam oferecer subsídios para professores/as e alunos/as sobre variadas manifestações de textos (...), contribuindo para o desenvolvimento de uma melhor compreensão dos papéis e do poder da linguagem. (...) visam também ter repercussões práticas relativas à análise e produção de textos na escola.

23. Theo van Leeuwen is mentioned in the homepages of MAL and the CMR, besides his local participation in the Creative Practice and Cultural Economy Research Centre at University of Technology, Sydney.

24. See examples in section 3.2.

25. For example, MAL allows the download of trial versions of softwares for multimodal analysis as well as video tutorials on these products.

\section{References}

Agarwall-Hollands, U., \& Andrews, R. (2001). From scroll to codex... and back again. Education, Communication, Information, 1(1), 59-73.

Almeida, D. B. L. (2009). Where have all the children gone? A visual semiotic account of advertisements for fashion dolls. Visual Communication, 8, 481-501.

Andrews, R., \& Smith, A. (2011). Developing writers: learning and teaching in the digital age. Maidenhead: Open University Press/McGraw-Hill. 
Baldry, A., \& Thibault, P. J. (2005). Multimodal transcription and text analysis: A multimedia toolkit and coursebook with associated on-line course. London/Oakville: Equinox.

Bezemer, J., \& Jewitt, C. (2009) Qualitative research methods: Multimodal analysis. Handbook of Linguistic Research Methods. London: Continuum.

Bezemer, J., \& Kress, G. (2008). Writing in multimodal texts: A social semiotic account of designs for learning. Written Communication, 25(2), 166-195.

Bezemer, J., \& Mavers, D. (2011). Multimodal transcription as academic practice: a social semiotic perspective. International Journal of Social Research Methodology, Special Issue on Video-Based Social Research: Theory and Practice, 14(3), 191-207.

Bezerra, F. (2008). 'SEX AND THE CITY': An investigation of women's image in Carrie Bradshaw's discourse as narrator. Dissertação de Mestrado. Pós-graduação em Inglês. Universidade Federal de Santa Catarina, Florianópolis, SC.

Bezerra, F. (2011). A imagem feminina em Sex and the City: uma análise de transitividade da narração. Revista Investigações, 24(2), 103-133.

Bezerra, F. (2012). Multimodality in the EFL classroom. Brazilian English Language Teaching Journal (BELT), 2(2), 167-177.

Bezerra, F. (2012). Language and image in the film 'Sex and the City': a multimodal investigation of the representation of women. Tese de Doutorado. Pós-graduação em Inglês. Universidade Federal de Santa Catarina, Florianópolis, SC.

Bezerra, F.; Nascimento, R. G.; Heberle, V. M. (2010). Análise multimodal de anúncios do programa 'Na Mão Certa'. Revista Letras (UFSM), Santa Maria, v. 20, n. 40, p. 9-26.

Böhlke, R. de F. (2008). Constructing ideal body appearance for women: A multimodal analysis of a TV advertisement. Tese de Doutorado. Pós-graduação em Inglês. Universidade Federal de Santa Catarina, Florianópolis, SC. 
164 Fábio Alexandre S. Bezerra and Roseli G. do Nascimento, The role of...

Callow, J. (Ed.). (1999). Image matters: Visual texts in the classroom. Marrickville, NSW: Primary English Teaching Association.

Catto, N. R., \& Hendges, G. R. (2009). Análise multimodal de gênero de tiras de quadrinho. In Anais IX Seminário Internacional em Letras: relações dialógicas em língua e literatura, Santa Maria: Centro Universitário Franciscano UNIFRA.

Ferreira, S. N. (2007). Bridging theories: A logical-functional perspective on languages. Semiotica, 167, 91-118.

Ferreira, S. N., \& Heberle, V. (2010). Semiotic change: a pilot study on textimage resources in modern and (post)modern ads. Revista Intercâmbio, 21, 98-117.

Flewitt, R.S. (2012). Multimodal perspectives on early childhood literacies. In J. Larson and J. Marsh (Eds), The SAGE handbook of early childhood literacy (2nd ed). London: Sage.

Frommherz, G. (2010). Art of decay and eternity - Ritualization in aipan practice. Visual Antrophology, 23(4), Special Issue: Visual Aspects of Ritual Behavior.

Gee, J. P. (2000). Discourse and sociocultural studies in reading. In M. L. Kamil, P. B. Mosenthal, P. D. Pearson, \& R. Barr (Eds.), Handbook of reading research (pp. 195-207), vol. III. New Jersey, USA: LEA.

Halliday, M. A. K. (1978). Language as Social Semiotic: the social interpretation of language and meaning. London: Edward Arnold.

Heberle, V. (1997). An investigation of textual and contextual parameters in editorials of women's magazines. Tese de Doutorado. Pós-graduação em Inglês. Universidade Federal de Santa Catarina, Florianópolis, SC.

Heberle V. (2010). Multimodal literacy for teenage EFL students. Caderno de Letras (UFRJ), 27, 101-116.

Heberle, V. M., Ostermann, A. C, \& Figueiredo, D. de C. (Eds.) (2006). Linguagem e gênero no trabalho, na mídia e em outros contextos. Florianópolis: Editora da UFSC. 
Heberle, V., \& Meurer, J. L. (2007). Aspects of visual analysis for the EFL class. Anais do I Congresso Internacional da ABRAPUI. UFMG.

Heberle, V., \& Abreu, B. (2012). Investigating multimodality: an analysis of students' diary journals. Linguagem em Foco, 1, 77-96.

Hendges, G. R. (2006a). Gramática da imagem: modalidades semióticas não-verbais em artigos acadêmicos de lingüística. In D. Motta-Roth, $\mathrm{N}$. C. de Barros, \& M. G. Richter. (Org.). Linguagem, cultura e sociedade. Santa Maria: Programa de Pós-Graduação em Letras, UFSM, pp. 23-38.

Hendges, G. R. (2006b). 'Yes, there are some hyperlinks, so what?': The metafunctional complexity of hyperlinks in written academic discourse. In Friday SFL Research Seminar, Sydney. Sys-func Digest, 30.

Hendges, G. R. (2008). Tackling genre classification: the case of HTML research articles, Tese de Doutorado. Pós-graduação em Inglês. Universidade Federal de Santa Catarina, Florianópolis, SC.

Hendges, G. R; Nascimento, R. G. \& Marques, P. M. (forthcoming). A gramática da imagem como ferramenta na análise crítica de gêneros midiáticos.

Hodge, R. and G. Kress. (1988). Social Semiotics. Cambridge: Polity

Hopperstad, M. H. (2008). How children make meaning through drawing and play. Visual Communication, 7(1), 77-96.

Iedema, R.A. (2003). 'Multimodality, resemiotization: Extending the Analysis of Discourse as Multi-Semiotic Practice', Visual Communication, 2(1), 29-57.

Jewitt, C. (2008). Multimodal classroom research. AERA Review of Research in Education, 32, 241-267.

Jewitt, C. (2009). Different approaches to multimodality. In C. Jewitt (ed). The Routledge Handbook for Multimodal Analysis. London: Routledge, p. 28-39.

Kellner, D. (2006). Technological transformation, multiple literacies, and the re-visioning of education. In J. Weiss et al. (Eds.), The international 
Fábio Alexandre S. Bezerra and Roseli G. do Nascimento, The role of...

handbook of virtual learning environments (pp. 241-268). Dordrecht: Springer.

Knox, J. (2007). Visual-verbal communication on online newspaper home pages. Visual Communication, 6(1), 19-53.

Kress, G. (2003). Literacy in the new media age. London/New York: Routledge.

Kress, G., \& van Leeuwen, T. (2001). Multimodal discourse: The modes and media of contemporary communication. London: Arnold.

Kress, G., \& van Leeuwen, T. (2006 [1996]). Reading images: The grammar of visual design. 2nd ed. London: Routledge.

Kress, G., Jewitt, C., Bourne, J., Franks, A., Hardcastle, J., Jones, K., \& Reid, E. (2005). English in urban classrooms. A multimodal perspective on teaching and learning. London: Routledge Falmer.

Lemke, J. (1998). Multiplying meaning: Visual and verbal semiotics in scientific text. In J.R. Martin \& R. Veel (Eds.), Reading Science. London: Routledge.

Lewin, C., Mavers, D., \& Somekh, B. (2003). Broadening access to the curriculum through using technology to link home and school: A critical analysis of reforms intended to improve students' educational attainment. The Curriculum Journal, 14(1), 23-25.

Lim, F. V. (2011). A systemic functional multimodal discourse analysis approach of pedagogic discourse. Unpublished PhD Thesis. Department of English Language and Literature, National University of Singapore.

Lim, F. V.; O'Halloran, K. L. \& Podlasov, A. (2012). Spatial Pedagogy: mapping meanings in the use of classroom space. Cambridge Journal of Education, 42(2), 235-251.

Liu, Y., \& O’Halloran, K. L. (2009). Intersemiotic texture: Analyzing cohesive devices between language and images. Social Semiotics. 19(4), 367-388.

Luke, C. (2006). Cyberpedagogy. In J. Weiss et al. (Eds.), The international handbook of virtual learning environments (pp. 269-277). Dordrecht: Springer. 
Machin, D. (2007). Introduction to multimodal analysis. London: Hodder Arnold.

Martin, J. (2010). Multimodal semiotics: theoretical challenges. In J. Martin, S. Hood, \& S. Dreyfus (Eds.). Semiotic margins: Reclaiming meaning. London: Continuum.

Mavers, D. (2008). Children's writing and drawing as design. New York/ London: Routledge.

Mavers, D. (2011) Children's drawing and writing: the remarkable in the unremarkable. New York: Routledge.

McDougall, J. (2010). A crisis of professional identity: How primary teachers are coming to terms with changing views of literacy. Teaching and Teacher Education, 26, 679-687.

Meurer, J. L. (2004). Role prescriptions, social practices, and social structures: a sociological basis for the contextualization of analysis in SFL and CDA. In L. Young \& C. Harrison (Eds.), Systemic functional linguistics and critical discourse analysis: Studies in social change (pp. 85102). London: Continuum.

Meurer, J. L.; Bonini, A. \& Motta-Roth, D. (Orgs.) (2005). Gêneros: teorias, métodos, debates. São Paulo: Parábola.

Motta-Roth, D. (2005). Being an e-fly on the wall, observing an EFL computer-mediated teacher. In L. M. B. Tomitch, M. H. Abrahão, C. Daghlian. \& D. I. Ristoff (Org.). A interculturalidade no ensino de inglês. Série ARES. Florianópolis, SC: PGI/UFSC, pp. 100-119.

Motta-Roth, D.; Hendges, G. R. (2010). Explorando modalidades retóricas sob a perspectiva da multimodalidade. Letras UFSM, Santa Maria, 20(40), 43-66.

Motta-Roth, D. M., \& Heberle, V. M. (2005). O conceito de "estrutura potencial do gênero" de Ruqayia Hasan. In José Luiz Meurer, Adair Bonini, \& Désirée Motta-Roth. (Org.). Gêneros: teorias, métodos, debates (pp. 12-28). São Paulo: Parábola Editorial. 
Motta-Roth, D. M., Reis, S. C. dos, \& Marshall, D. (2007). O gênero página pessoal e o ensino de produção textual em inglês. In Júlio César Araújo (Org.). Internet \& ensino: Novos gêneros, outros desafios. (pp.136-143). Rio de Janeiro: Lucena.

Motta-Roth, D., \& Nascimento, F. S. (2010). Transitivity in visual grammar: Concepts and applications. Linguagem \& Ensino, 12, 319-349.

Motta-Roth, D., Hendges, G. R., Amoretti, E. C., \& Kloss, M. (2000). $\mathrm{O}$ tradicional e o novo: Análise de artigos acadêmicos eletrônicos. Intercâmbio, 9, 29-38.

Nascimento, R. G. (2002). A interface texto verbal e não-verbal no artigo acadêmico de Engenharia Elétrica. Dissertação de Mestrado. Pósgraduação em Letras. Universidade Federal de Santa Maria.

Nascimento. R. G., Bezerra, F., \& Heberle, V. (2011). Multiletramentos: iniciação à análise de imagens. Linguagem \& Ensino (online), 14(2), 529552.

Nascimento, R. G. (2012). Research genres and multiliteracies: channelling the audience's gaze in PowerPoint presentations. Tese de Doutorado. Pós-graduação em Inglês. Universidade Federal de Santa Catarina, Florianópolis, SC.

Nascimento, R. G., \& Motta-Roth, D. (2004). Contributions of systemic functional grammar to the study of non-verbal texts in research articles of electrical engineering. In Primera Conferecia Latinoamericana de Lingüística Sistémico-Funcional. Universidad Nacional de Cuyo: Mendoza, Argentina.

Nascimento, R. G.; Bezerra, F.; Heberle, V. M. (2010). Multiletramentos: iniciação à análise de imagens. Linguagem \& Ensino, v. 14, n. 2, p. 529552, jul./dez 2011.

Norris, S. (2009). Modal density and modal configurations: Multimodal actions. In C. Jewitt (Ed). Handbook for multimodal discourse analysis. London: Routledge.

Norris, S. (2010). Identity in interaction: Introducing multimodal interaction analysis. Berlin/New York: de Gruyter. 
Norris, S. (2011). Identity in (Inter)action: Introducing Multimodal (Inter) action Analysis. Trends in Applied Linguistics, v. 4, Germany: De Gruyter Mouton. Analysis of personal identity construction of a German-Italian woman: A method applicable to film, theatre, dance, and novels.

O'Halloran, K. L. (2007). Multimodal analysis and digital technology. In A. Baldry, \& E. Montagna (Eds.), Interdisciplinary perspectives on multimodality: Theory and practice. Campobasso: Palladino.

O'Halloran, K. L. (2008). Systemic functional-multimodal discourse analysis (SF-MDA): constructing ideational meaning using language and visual imagery. Visual Communication, 7(4), 443-475.

O'Halloran, K. L., Tan, S., Smith, B. A., \& Podlasov, A. (2010). Challenges in designing digital interfaces for the study of multimodal phenomena. Information Design Journal, 18(1), 2-12.

O'Halloran, K. L., Tan, S., Smith, B. A., \& Podlasov, A. (2011). Multimodal discourse: Critical analysis within an interactive software environment. Critical Discourse Studies, 8(2), 109-125.

O'Halloran, K. L., E, M. K. L. \& Tan, S. (2009). Multimodal analytics: software and visualization techniques for analyzing and interpreting multimodal data. In C. Jewitt (Ed.), Handbook of multimodal analysis ( $2^{\text {nd }}$ edition). London: Routledge.

O'Toole, M. (1994). The language of displayed art. Rutherford, NJ: Fairleigh Dickinson University Press.

Oliveira, F. M. (2009) A análise de propostas pedagógicas em portais educacionais para docentes da língua inglesa: Implicações para o ensino e a aprendizagem de línguas no contexto digital. Tese de Doutorado. Pós-graduação em Letras. Universidade Federal de Santa Maria, Santa Maria.

Ostermann, A. C. (1995). Good girls go to heaven; bad girls... learn to be good: critical discourse analysis of quizzes in teenage girls' magazines. Dissertação de Mestrado. Pós-graduação em Inglês. Universidade Federal de Santa Catarina, Florianópolis, SC. 
Prawucki, R. (1998). "Girls don't climb trees; boys don't cry": a critical discourse analysis of gender roles in narrative for children. Dissertação de Mestrado. Pós-graduação em Inglês. Universidade Federal de Santa Catarina, Florianópolis, SC.

Rüther, R, \& Montenegro, A. (Org.) (2009). Diretório de grupos de pesquisa da UFSC: Censo 2008. Florianópolis: UFSC.

Santiago, M. E. V., \& Meurer, J. L. (2008). EFL teachers' discourse at Orkut: Agency from the perspective of systemic functional linguistics and structuration theory. Intercâmbio, 17, 322-343.

Somerville, M. (2008). Re-thinking literacy as a process of translation. Australian Journal of Language and Literacy, 32(1), 9-21.

Soundy, C, \& Drucker, M. (2010). Picture partners: a co-creative journey into visual literacy. Early Childhood Education Journal, 37, 447-460.

Souza, A. A. (2006). The construal of interpersonal meanings in the discourse of national anthems: An appraisal analysis. In Proceedings of the 33rd International Systemic Functional Congress. São Paulo: LAEL/ PUC-SP, pp. 531-550.

Stenglin, M. (2009). Space odyssey: Towards a social semiotic model of three-dimensional space. Visual Communication, 8(1), 35-64.

Tan, S.; E, M. K. L. \& O’Halloran, K. L. (2012). Multimodal analysis image (Teacher Edition and Student Edition). Multimodal Analysis Company: Singapore.

The New London Group (1996). A pedagogy of multiliteracies: Designing social futures. Harvard Educational Review, 66(1), 60-93.

Thibault, P. J. (2000). The multimodal transcription of a television advertisement: theory and practice. In A. Baldry (Ed.), Multimodality and multimediality in the distance learning age, (pp. 311-384). Campobasso: Palladino.

Ticks, L. K. (2003). Contribuições da análise de gênero para o estudo de conceitos de linguagem em livros didáticos e no discurso de professoras de inglês. Dissertação de Mestrado. Pós-graduação em Letras. Universidade Federal de Santa Maria, Santa Maria. 
Unsworth, L. (2001). Teaching multiliteracies across the curriculum: Changing contexts of text and image in classroom practice. Buckingham, UK: Open University.

van Leeuwen, T. (1999). Speech, music, sound. London: Macmillan.

Weissman, L.D.M. (2005).Propósitos educacionais no meio on-line: o caso dos cursos de inglês gratuítos. Dissertação de mestrado. Pós-graduação em Letras. Universidade Federal de Santa Maria.

White, P. (2010). Grabbing attention: the importance of modal density in advertising. Visual Communication. 9(4), 371-397. London: Sage Publishing.

[Received in 31/05/2013. Approved in 02/07/2013] 
